\title{
Diagnostic of Biomphalaria Snails and Schistosoma mansoni: DNA O btained from Traces of Shell Organic Materials
}

\author{
Roberta L Caldeira, Liana K Jannotti-Passos, Pollanah M Lira, 0 mar S Carvalho+
}

Centro de Pesquisas René Rachou-Fiocruz, Av. Augusto de Lima 1715, 30190-002 Belo Horizonte, MG, Brasil

Freshwater snails belonging to the genus Biomphalaria act as intermediate hosts for the parasite trematode Schistosoma mansoni in Africa and in the neotropical region. Identification of such molluscs is carried out based on morphological characters and the presence of cercariae is verified through squeezing snails between two glass slides or by exposing them to artificial light. However, sometimes, the material collected includes molluscs with decomposed bodies or, yet, only empty shells, which precludes their identification and $\mathrm{S}$. mansoni detection. Due to these difficulties, we have developed a methodology in which DNA may be extracted from traces of organic material from inside shells in order to identify molluscs through polymerase chain reaction and restriction fragment length polymorphism and to detect $\mathrm{S}$. mansoni into these snails, by using low stringency polymerase chain reaction. Species-specific profiles obtained from B. glabrata, B. straminea, and B. tenagophila snails and their shells, maintained in laboratory for ten years, showed the same profiles. S. mansoni profiles showed to be present in shell specimens as far as the eighth week after being removed from aquarium.

Key words: Biomphalaria - Schistosoma mansoni - molluscs - shell - DNA - polymerase chain reaction

There are 34 identified species of the genus Biomphalaria (Mollusca: Planorbidae) in Africa and in the Neotropic region, out of which B. glabrata, B. tenagophila, B. straminea, B. prona, B. pfeifferi, B. sudanica, $B$. alexandrina $B$. choanomphala, B. camerunensis, and $B$. stanley are regarded as intermediate hosts of the trematode Schistosoma mansoni, the aethiological agent of human intestinal schistosomiasis (Malek 1985, Brown 1994, Noya et al. 1999).

The identification of such molluscs is normally carried out based on morphological characters of the shell, renal, and reproductive systems (Paraense 1975). However, the identification of some species may become complicated due to the similarity among these characters (Paraense 1988). Recently, molecular tools based on polymerase chain reaction and restriction fragment length polymorphism (PCR-RFLP) of the ribosomal RNA intergenic spacer regions (ITS) have been used in order to overcome this problem (Vidigal et al. 1998, Caldeira et al. 1998, 2000).

The detection of Biomphalaria snails infected with $S$. mansoni is usually performed by cercariae shedding induced by artificial light exposure or by squeezing snails between two glass slides. However, these methods are not able to detect the parasite neither in dead snails nor in the pre-patent period. In the latter, infection diagnosis is only possible after the parasite has completed its life cycle (3 to 4 weeks after infection), when cercariae release is started. Thus, molecular methods have been used to de-

Partial financial support: Fapemig, Pibic/Fiocruz

${ }^{+}$Corresponding author. Fax: +55-31-3295.3115. E-mail: omar@cpqrr.fiocruz.br

Received 8 September 2003

Accepted 16 June 2004 tect $S$. mansoni infection for both the situations (Hanelt et al. 1997, Jannotti-Passos et al. 1997, Hamburger et al. 1998).

Sometimes, the material collected and sent to laboratory for identification purposes includes molluscs with decomposed bodies or, yet, only empty shells, which precludes their identification and $S$. mansoni detection. Due to these difficulties, we have developed a methodology in which DNA may be extracted from traces of organic material from inside the shells in order to identify molluscs using PCR-RFLP of the ITS2 region and to detect possible infections by $S$. mansoni, through low stringency (LS-PCR) using tandem repeated region of mtDNA from $S$. mansoni.

\section{MATERIALS AND METHODS}

Snails population - Biomphalaria shells and their respective cephalopodal regions from the following species: B. glabrata (8-19 mm diameter), B. tenagophila (5-13 $\mathrm{mm})$, and B. straminea $(5-7 \mathrm{~mm})$ were used. This material had been maintained in a Malacological Collection at the Laboratory of Intestinal Helminthiasis of Centro de Pesquisas René Rachou-Fiocruz (Table). In addition, three empty shells, randomly collected in the field, were used (Jaboticatubas, Minas Gerais, Brazil).

Artificially dried B. glabrata snails infected with $S$. mansoni - Fifty specimens of B. glabrata (10-12 mm), shed$\operatorname{ding} S$. mansoni cercariae (experimental infection with LE strain: 10 miracidia/mollusc), were recovered from aquarium and kept in platters at room temperature for decomposition. DNA was weekly extracted, during eight weeks, from three shells that had already had their soft part decomposed.

DNA extraction - The shells were washed with distilled water and then had their central whorl perforated in a single side. Following, they were immersed into $50 \mathrm{mM}$ Tris HCL pH 8.0, 100 mM NaCl, 50 mM EDTA, 0.5\% SDS and incubated with $25 \mu \mathrm{g} / \mathrm{ml}$ proteinase $\mathrm{K}$, at $37^{\circ} \mathrm{C}$ for 
TABLE

Species, date of snail insertion in the collection and snails locality origin

\begin{tabular}{lccl}
\hline Species & Nr of specimens & $\begin{array}{c}\text { Date of snail insertion } \\
\text { in the collection }\end{array}$ & Localities \\
\hline Biomphalaria glabrata & 2 & 1993 & Minas Gerais/Brazil \\
& 1 & 1994 & Minas Gerais/Brazil \\
& 1 & 1997 & Portuguesa/Venezuela \\
& 1 & 1998 & Rio Grande do Sul/Brazil \\
Guárico/Venezuela
\end{tabular}

five days. Afterwards, the shells were removed from this solution, washed with distilled water, and returned to the collection. Then, phenol/chloroform extraction and ethanol precipitation were carried out. DNA was resuspended in $10 \mathrm{mM}$ Tris-HCl, $1 \mathrm{mM}$ EDTA pH 8.0.

As control group, DNA from the cephalopodal region of $S$. mansoni infection-free snails (without infection) and $S$. mansoni (LE) adult worms were used.

PCR-RFLP analysis - The entire ITS2 region from snails was amplified using the primers ITS2F (5'-CGTCCGT CTGAGGGTCGGTTTGC-3') and ETTS1 (5-TGCTTAA GTTCAGCGGGT-3), anchored, respectively, in the conserved extremities of the $5.8 \mathrm{~S}$ and $28 \mathrm{~S}$ ribosomal genes (Kane \& Rollinson 1994, Vidigal et al. 2000). PCR amplification and RFLP conditions, using HpaII enzyme were the same as used by Vidigal et al. (2004). Products were visualised on $6 \%$ silver stained polyacrylamide gels and the results were recorded with the camera Mavica (Sony).

$L S$ - $P C R$ - DNA extracted from artificially dried snails was amplified through LS-PCR, using the primers ER 5' ACCTACCGTACTATGACG 3' and EF 5' GGT TTCTT AGTGTTATAGCC 3' (Jannotti Passos et al. 1997), as well as adult worm DNA. These primers amplified the tandem repeated region of mitochondrial DNA from $S$. mansoni. The reaction conditions were the same as those used by Jannotti-Passos et al. (1997). Products were visualised on $6 \%$ silver stained polyacrylamide gels and the results were recorded with the camera Mavica (Sony).

\section{RESULTS}

PCR-RFLP analysis - DNA amplification with the ITS2F and ETTS1 primers generated one fragment of ap- proximately $460 \mathrm{bp}$ for all specimens (data not shown). All samples had their profiles reproducible, but only three specimens of each species are demonstrated here. The Figure shows RFLP profiles obtained after digestion of rRNA ITS2 with HpaII enzyme. From traces of shell organic material distinct profiles were obtained for $B$. glabrata (four fragments), $B$. straminea (two), and $B$. tenagophila (four), which showed to be identical to those obtained from their cephalopodal region.

$L S-P C R$ - Profiles obtained through LS-PCR, for artificially dried snails infected with $S$. mansoni (lanes 23-28), were similar to the adult worm profile (lane 22), which corresponds to the amplification of the tandem repeated region of the $62 \mathrm{bp}$ fragment from $S$. mansoni.

\section{DISCUSSION}

The current study reports on DNA obtained from shells of Biomphalaria snails, which have been deposited in a malacological collection for 10 years. From such DNA, it was possible to perform a specific identification of Brazilian molluscs, $S$. mansoni intermediate hosts, through PCRRFLP. Further, the detection of $S$. mansoni from artificially infected snails, dried throughout eight weeks, was also carried out.

The methodology based on PCR-RFLP, using the ITS region of rDNA, was successfully used in order to define species-specific patterns of Neotropical Biomphalaria snails and in study of species usually difficult to be identified by morphological techniques (Vidigal et al. 1998, 2000, 2001, Caldeira et al. 1998, 2000, Spatz et al. 1999, 2000). It is known that the amplification of such region generates a fragment of $1300 \mathrm{bp}$, however, in the present 


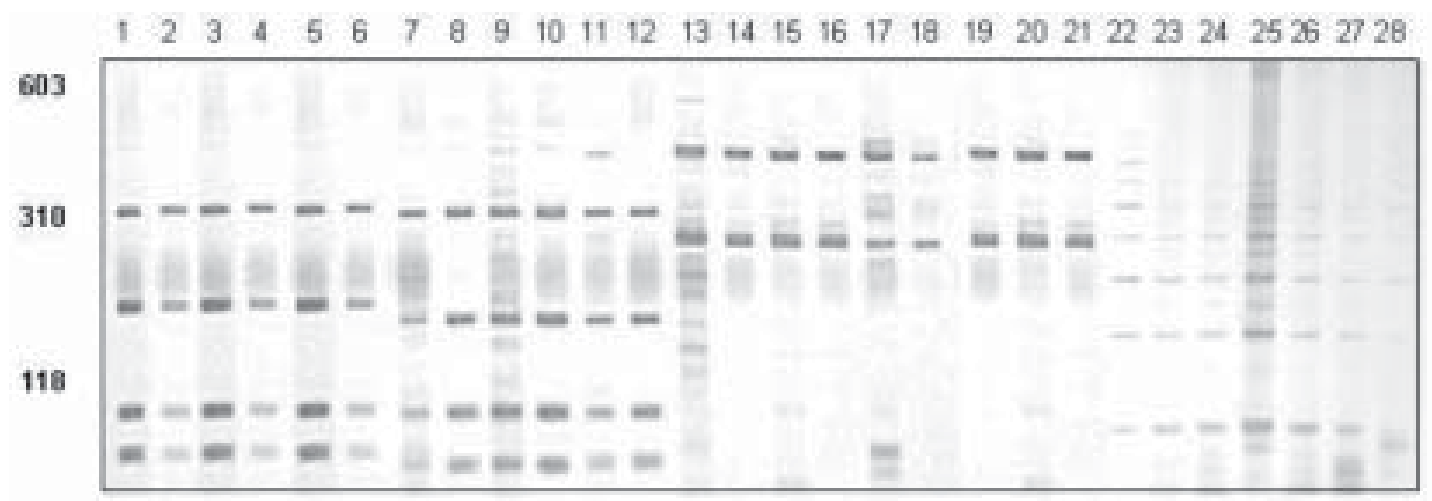

6\% silver stained polyacrylamide gel. Lanes 1 to 21 show polymerase chain reaction restriction fragment length polymerase profiles obtained following the digestion of ribosomal RNA of second internal transcribed spacer region with HpaII. Odd lanes (1 to 17) correspond to the cephalopodal region profile and even lanes (2 to 18) to traces of organic material from shells. Lanes - 1, 2: Biomphalaria glabrata from from Minas Gerais, Brazil (deposited in the collection of Centro de Pesquisas René Rachou-Fiocruz, in 1993); 3, 4: B. glabrata Portuguesa, Venezuela (1997); 5, 6: B. glabrata from Rio Grande Sul, Brazil (1998); 7, 8: B. tenagophila from Rio de Janeiro, Brazil (1993); 9, 10: B. tenagophila from Santa Catarina, Brazil (1993); 11, 12: B. tenagophila from Minas Gerais, Brazil (1997); 13, 14: B. straminea from Pará, Brazil (1993); 15, 16: B. straminea from Paraná, Brazil (1993); 17, 18: B. straminea from Pernambuco, Brazil (1997); 19, 21: show profiles of traces of organic material from the inside shells of B. straminea from Minas Gerais, Brazil, randomly collected in the field (2002). Lanes 22 to 28 show Schistosoma mansoni profiles obtained through low stringency polymerase chain reaction. Lanes - 22: profile of an adult worm; 23 to 25: S. mansoni profiles from organic material traces from the inside shells of infected B. glabrata, in decomposition at room temperature for seven weeks; 26, 28: S. mansoni profiles from organic material traces from the inside shells of infected $B$. glabrata, in decomposition at room temperature for eight weeks. Molecular size markers are shown on the left of the gel.

study, a shorter region was used, once target DNA could be degraded. Aimed at confirming the profiles obtained by PCR-RFLP of shells, we used, as a comparison parameter, DNA extracted from the cephalopodal region from the snails under study. This strategy turned our results more reliable, precluding the possibility of amplifying other organisms DNA, which would be contaminating our material.

Molecular techniques for S. mansoni detection in snails have been used as a complementary tool when the conventional techniques are not efficient to do so. Indeed, Hamburger et al. (1992) diagnosed S. mansoni in Biomphalaria sp., through a DNA probe marked with ${ }^{32} \mathrm{P}$ directed to a repeated genome region of the parasite. However, such method offers the inconvenient use of a radioactive substance. Hanelt et al. (1997) were able to detect the presence of $S$. mansoni in B. glabrata snails, during the pre-patent period, and distinguished S. mansoni between two other trematode by amplifying its $18 \mathrm{~S}$ region from rDNA through "nested" PCR. This methodology involves two PCR reactions, which is long lasting and laborious. Besides, the lack of an intern control turns a possible negative result, corresponding to the absence of infection, to be undetectable. By amplifying a $121 \mathrm{bp}$ repeated region from S. mansoni, Hamburger et al. (1998) detected its presence in B. glabrata snails during the prepatent period through one PCR reaction. In further studies, Jannotti-Passos et al. (1997) were able to detect the presence of $S$. mansoni in B. glabrata snails until $72 \mathrm{~h}$ after death, and distinguished $S$. mansoni among other trematode through mitochondrial DNA repeated region amplification using LS-PCR. This reaction is rapidly executed with a high sensitivity. In the present study, this technique was carried out in order to detect $S$. mansoni by obtaining traces of organic material from inside the shells, artificially dried up to eight weeks, enabling its possible use for epidemiological studies.

The results from the current work are an important breakthrough once it shows to be possible to recover sufficient DNA from traces of organic material into the shells for molecular studies. Furthermore, they represent promising possibilities for retrospective studies on geographical distribution of snail species or shells with a questionable classification in malacological collections or empty shells in collection sites.

\section{ACKNOWLEDGEMENTS}

To José Geraldo Amorim for technical assistance and Dr Naftale Katz for suggestions.

\section{REFERENCES}

Brown DS 1994. Freshwater Snails of Africa and their Medical Importance, 2nd ed., Taylor \& Francis, London.

Caldeira RL, Vidigal THDA, Matinella L, Simpson AJG, Carvalho OS 2000. Study of planorbids from Venezuela by polymerase chain reaction amplification and restriction fragment length polymorphism (PCR-RFLP). Mem Inst Oswaldo Cruz 95: 171-177.

Caldeira RL, Vidigal THDA, Paulinelli ST, Simpson AJG, Carvalho OS 1998. Molecular identification of similar species of the genus Biomphalaria (Mollusca: Planorbidae) determined by PCR-RFLP. Mem Inst Oswaldo Cruz, 93: 219-225.

Hamburger J, He-Na, Xin XY, Ramzy RM, Jourdane J, Ruppel A 1998. A polymerase chain reaction assay for detecting snails infected with bilharzia parasites (Schistosoma mansoni) from very early prepatency. Am J Trop Med Hyg 59: 872-876

Hamburger J, Weil M, Ouma JH, Koech D, Sturrock RF 1992. Identification of schistosome-infected snails by detecting 
schistosomal antigens and DNA sequences. Mem Inst Oswaldo Cruz 87: 243-247.

Hanelt B, Adema CM, Mansour MH, Loker ES 1997. Detection of Schistosoma mansoni in Biomphalaria using nested PCR. J Paraitol 83: 387-394.

Jannotti-Passos LK, Vidigal THDA, Dias-Neto E, Pena SDJ, Simpson AJG, Dutra WO, Souza CP, Carvalho-Parra JF 1997. PCR amplification of the mitochondrial DNA minisatellite region to detect Schistosoma mansoni infection in Biomphalaria glabrata snails. J Parasitol 83: 395399.

Kane RA, Rollinson D 1994. Repetitive sequences in the ribosomal DNA internal transcribed spacer of Schistosoma haematobium, Schistosoma intercalatum and Schistosoma mattheii. Mol Biochem Parasitol 63: 153-156.

Malek EA 1985. Snails Hosts of Schistosomiasis and Other Snail-transmitted Diseases in Tropical America, Manual, Pan American Health Organization, Scientific Publication no. 478,325 pp.

Noya BA, Balzan C, Arteaga C, Cesari I, Noya O 1999. The last fifteen years of schistosomiasis in Venezuela: features and evolution. Mem Inst Oswaldo Cruz 94: 139-146.

Paraense WL 1975. Estado atual da sistemática dos planorbídeos brasileiros. Arq Mus Nac Rio de Janeiro 55: 105-128.

Paraense WL 1988. Biomphalaria kuhniana (Clessin, 1883), planorbid mollusc from South America. Mem Inst Oswaldo Cruz 83: 1-12.

Spatz L, Vidigal THDA, Caldeira RL, Dias Neto E, Cappa SMG, Carvalho OS 1999. Study of Biomphalaria tenagophila, B. t. guaibensis and B. occidentalis by polymerase chain reaction amplification and restriction enzyme digestion of the ribosomal RNA gene intergenic spacer. $J$ Moll Stud 65:143-149.

Spatz L, Vidigal THDA, Silva MCA, González Cappa SM, Carvalho OS 2000. Characterization of Biomphalaria orbignyi, $B$. peregrina, and $B$. oligoza by polymerase chain reaction and restriction enzyme digestion of the internal transcribed spacer region of the RNA ribosomal gene. Mem Inst Oswaldo Cruz 95: 807-814.

Vidigal THDA, Caldeira RL, Simpson AJG, Carvalho OS 2001. Identification of Biomphalaria havanensis and Biomphalaria obstructa populations from Cuba using polymerase chain reaction and restriction fragment length polymorphism of the ribosomal RNA intergenic spacer. Mem Inst Oswaldo Cruz 96: 661-665.

Vidigal THDA, Kissinger JC, Caldeira RL, Pires ECR, Monteiro E, Simpson AJG, Carvalho OS 2000. Phylogenetic relationships among Brazilian Biomphalaria species (Mollusca: Planorbidae) based upon analysis of ribosomal ITS2 sequences. Parasitology 121: 611-620.

Vidigal THDA, Magalhães KG, Carvalho OS 2004. Polymerase chain reaction and restriction fragment length polymorphism analysis (PCR-RFLP) of the ITS2 region for identification of Brazilian Biomphalaria intermediate hosts of the Schistosoma mansoni. Rev Soc Bras Med Trop (in press).

Vidigal THDA, Spatz L, Nunes DN, Simpson AJG, Carvalho OS, Dias Neto E 1998. Biomphalaria spp: identification of the intermediate snail hosts of Schistosoma mansoni by polymerase chain reaction amplification and restriction enzyme digestion of the ribosomal RNA gene intergenic spacer. Exp Parasitol 89: 180-187. 